\title{
A közös agrárpolitika 2013. évi közvetlen támogatási rendszerének hatásai a magyar mezőgazdaságra
}

\begin{abstract}
Az agrárpolitika hatása meghatározó a mezőgazdasági szektor szempontjából, különösen így van ez az Európai Unió közös agrárpolitikájának (KAP) az esetében. Kiemelt fontosságúak a támogatások, illetve a lehívásukhoz szükséges elöírások ismerete és teljesítése. A KAP reformjai között jelenleg a 2013-as az utolsó, amelynek során több új intézkedést is bevezettek. Ezek között - a hozzájuk rendelt források nagysága alapján - az alaptámogatás és a zöldítés volt a legjelentősebb. Mivel a támogatások a mezőgazdasági szektorban képződő jövedelem jelentős részét teszik ki, így a tanulmány alaphipotézise, hogy az érintett termelési egységek (egyéni gazdaságok, társas vállalkozások) gazdaságilag racionális válaszokat adtak a támogatási rendszer megváltozására. Ez a gyakorlatban azt jelenti, hogy megpróbáltak teljes mértékben alkalmazkodni a reform jelentette változásokhoz a támogatások maximalizálása érdekében.*

Journal of Economic Literature (JEL) kód: Q12, Q18.
\end{abstract}

Az 1962-ben elfogadott közös agrárpolitika (KAP) sokáig az egyetlen teljesen integrált politika volt Európában (EC [2012]). A kiinduló formája az akkori követelmények miatt erősen termelésorientált volt, ami az önellátás elérése után már komoly problémákat okozott (például túltermelés, drága müködtetés). Ennek kezelése érdekében történt először egy kisebb horderejü kiigazítás, amit - eddig - öt érdemi reform (1992, 2000, 2003, 2008 és 2013) követett. ${ }^{1}$

Az agrárpolitikához történő - lehetőség szerint proaktív - alkalmazkodás az egyre élesedő uniós versenyben is kulcsfontosságú. Tisztában kell lenni a különböző előírásokkal, valamint meg kell felelni a jogosultsági kritériumoknak. Ez különösen jelentős Magyarországon, mivel a mezőgazdasági szektor összesített jövedelemtermelő

* A szerző köszönetet mond a Magyar Államkincstárnak az adatszolgáltatásért, valamint Rieger László tanácsadónak a publikáció elkészítéséhez nyújtott segítségéért.

${ }^{1}$ Az egyes reformok részletes leírását Jámbor-Mizik [2014] tartalmazza.

Mizik Tamás egyetemi docens, BCE Vállalkozásfejlesztési Intézet, Agrárközgazdasági és Vidékfejlesztési Tanszék (e-mail: tamas.mizik@uni-corvinus.hu). 
képessége 2017-ben 715,5 milliárd forint volt, aminek közel 60 százalékát (423,8 milliárd forint) tette ki a döntően az EU-tól különféle jogcímeken - zömmel közvetlen támogatás formájában - érkezett támogatás (KSH [2019a]). Ilyen nagyfokú függőségnél alapvető fontosságú a támogatási rendszer ismerete és a felkészültség a jövőben várható változásokra a lehetö legteljesebb körü alkalmazkodás érdekében.

Jelen tanulmány a legutolsó - a Dacian Cioloș akkori mezőgazdasági biztos vezetésével lezajlott - reform első pillérével (Európai Mezőgazdasági és Garancia Alap, EMGA) kapcsolatos intézkedéseknek a magyar mezögazdaságra gyakorolt hatásait elemzi. ${ }^{2}$ A reform legfontosabb elemeinek ismertetését a kapcsolódó szakirodalom elemzése követi. Majd mindennek a magyar mezőgazdaságra gyakorolt hatásait ismertetjük és értékeljük részletesen. Végül összefoglaljuk eredményeinket, és megfogalmazzuk javaslatainkat.

\section{A Cioloș-reform}

A 2013-as reform több okból sem lett/lehetett mélyreható. A mezőgazdasági biztos érdekérvényesítö képessége korlátozott volt, amit részben az okozott, hogy az első hivatali ciklusát töltötte, szemben például a 2003-as reform idején a második ciklusában járó Franz Fischlerrel. Azt sem szabad figyelmen kívül hagyni, hogy idöközben megváltozott a döntéshozatali mechanizmus (együtt döntés), ami tovább nehezítette az érdemi változások keresztülvitelét (Swinnen [2015]). A KAP jövőbeli zöldítése érdekében az Európai Bizottságnak mindenképpen változtatnia kellett a reformstratégiáján (Gravey [2015]).

\section{A reform legfontosabb elemei}

A Cioloș-reform első pilléres (közvetlen) támogatásainak legfontosabb elemei a következők voltak (Jámbor-Mizik [2014]).

- Alaptámogatás. Pénzügyi szempontból a legjelentősebb tétel. Ehhez kapcsolódóan két fontos fogalom a degresszivitás és a maximalizálás (capping). Az előbbi a 150 ezer euró/gazdaság közvetlen támogatási mértéktöl kötelezö, minimum 5 százalékos csökkentést, míg az utóbbi ezen kifizetések - bizonyos szint feletti - teljes elvonását jelenti.

- Zöldítés. A közvetlen támogatásnak kötelezően 30 százalékát teszi ki, és három kritériumot ír elö: terménydiverzifikáció, ökológiai célterület kialakítása (Ecological Focus Area, EFA) és az állandó gyepterület fenntartása.

- Termeléshez kötött támogatás, amely esetében a támogatás feltétele a mezőgazdasági termelés fenntartása.

\footnotetext{
${ }^{2}$ Az első pillér alapvetően a közvetlen támogatásokat, míg a második pillér a vidékfejlesztési célok megvalósulásához rendelkezésre álló forrásokat tartalmazza. A Cioloș-reform kapcsán azonban meg kell jegyezni, hogy ez a szétválasztás nem volt egyértelmü, hiszen például bizonyos környezeti többletteljesítmények (zöldítés), illetve a fiatal gazdák támogatása is mindkét pillérből finanszírozható volt. Ennek érdekében volt szükség a kettős finanszírozás tilalmának a bevezetésére.
} 
- Fiatal gazdák támogatása, amely kizárólag 40 éves kor alatt igényelhető.

- A kisgazdaságok egyszerüsített adminisztráció mellett 500-1250 euró/év nagyságú átalánytámogatást igényelhettek.

A hazai nemzeti boríték - egy adott tagországnak a közvetlen kifizetésre rendelkezésére álló összeg - felosztását mutatja be az 1. táblázat a felsorolt támogatásfajták szerint.

\section{1. táblázat}

A 2016. évi magyar nemzeti boríték összetétele

\begin{tabular}{lccc}
\hline Nemzeti boríték & $\begin{array}{c}\text { A támogatások } \\
\text { megoszlása (százalék) }\end{array}$ & $\begin{array}{c}\text { Tényleges kifizetés } \\
\text { (milliárd forint) }\end{array}$ & $\begin{array}{c}\text { A kifizetések } \\
\text { megoszlása (százalék) }\end{array}$ \\
\hline Zöldítés & 30,00 & 154,41 & 32,23 \\
Fiatal gazda & 0,62 & 4,49 & 0,94 \\
Termeléshez kötött & 13,00 & 59,88 & 12,50 \\
Termeléshez kötött, fehérje & 2,00 & & 1,93 \\
Kisgazdaságok & 0,55 & 9,26 & 52,41 \\
Alaptámogatás (SAPS) & 53,83 & 251,09 & 100,00 \\
Összesen & 100,00 & 479,13 & \\
\hline
\end{tabular}

* Egységes területalapú támogatás (single area payment scheme, SAPS).

Megjegyzés: a táblázatban szereplő tényleges kifizetések az előleg fizetése miatt két gazdasági évre vonatkoznak (a tárgyévi végkifizetés és a következö évi elöleg).

Forrás: Algeier [2015] és MK [2018] alapján saját szerkesztés.

A zöldítés részaránya minden tagállamban rögzített, a közvetlen kifizetések 30 százalékát teszi ki. A felsorolt három feltételt kell hozzá betartani, illetve speciális kivétel, ha a gazdaság valamilyen agrár-környezetvédelmi célprogramban vesz részt, vagy biotermelő (már az átállás időszakában is), mert akkor automatikusan mentesül ezek alól. Erre a kifizetésre nem alkalmazható a degresszivitás és a maximalizálás.

A fiatalgazda-támogatás részaránya, illetve nagysága attól függ, hogy mekkora a potenciális jogosultak létszáma, és közülük mennyien pályáznak rá. A magyar rendszer egyik sajátossága a termeléshez között támogatás maximalizálása, ami fehérjenövények termelése esetén a nemzeti boríték 15 százalékát teszi ki (13+2 százalék).

A kisgazdaságok támogatása a fiatal gazdák támogatásához hasonló, tehát az össznagyságát az igénylés nagysága határozza meg. Ebben az esetben nem kell megfelelni például a zöldítési kritériumoknak, viszont a támogatás összege is limitált, maximum 1250 euró lehet évente. ${ }^{3} \mathrm{Ez}$ akár akkor is észszerü megoldás lehet, ha egyébként nagyobb támogatásra lenne jogosult az érintett termelö, de például nem kívánja megörizni az állandó gyepterületét, hanem azon intenzívebb termelést tervez. A belépési szándékot 2015. augusztus 15-ig lehetett bejelenteni, és az akkor megállapított támogatást a 2020-ig tartó periódus végéig évente folyósítják,

\footnotetext{
${ }^{3}$ Ebbe természetesen nem számítanak bele az úgynevezett nem közvetlen kifizetések, mint amilyen például az átmeneti nemzeti támogatás vagy az állatjóléti támogatás.
} 
amennyiben a gazdálkodó jogosult összterületének nagysága megmarad [16/2015. (IV. 9.) FM-rendelet].

A Nemzeti Agrárgazdasági Kamara (NAK) támogatáskalkulátora alapján ${ }^{4}$ a maximális támogatás nagyjából 5,5 hektárnyi föld esetén azonos a közvetlen támogatásokkal (alaptámogatás + zöldítés), míg az 500 eurós minimumösszegnél ez az érték 2,2 hektár (https://www.nak.hu/kapcalk). Ez utóbbi esetben 2,2 hektár alatti földterülettel is lehet pályázni, mivel akkor az átalánytámogatás összege 500 euróra lesz felkerekítve.

Végül a magyar nemzeti boríték legnagyobb részét, közel 54 százalékát az alaptámogatás teszi ki, amelynek a nagysága a táblázatban szereplő elemek részarányának a 100 százalékból történő levonásával megy végbe. Magyarország a 150 ezer euró/gazdaság (1037-1200 hektár közötti üzemméret) közvetlen támogatási mértéktől kötelező, minimum 5 százalékos csökkentés (degresszivitás) mellett a 176 ezer euró feletti (ami 1200 hektárnál nagyobb területen történő gazdálkodást jelent) támogatás teljes elvonását (maximalizálás) alkalmazta (Szabó [2017]).

$\mathrm{Az}$ 1. táblázat utolsó két oszlopa a tényleges kifizetéseket és azok arányát mutatja. Az eltérés a nemzeti boríték felosztásától még annak ellenére sem jelentős, hogy nem tisztán a 2016-os év adatait tartalmazza az előlegfizetés miatt. Jól érzékelteti azonban az első pillér fontosságát, mivel abban az évben az összes agrár- és vidékfejlesztési támogatás 654,11 milliárd forint volt (közvetlen támogatások, vidékfejlesztési és halászati támogatások, piaci, valamint nemzeti támogatások együttesen), amelynek a táblázatban szereplő 479,13 milliárd forint a 73,25 százalékát tette ki (MK [2018]).

A 2013-as reform azonban a 2003-as reform több eleméhez sem nyúlt hozzá (például a keresztmegfelelés ${ }^{5}$ vagy a támogatásoknak a termelésről történő leválasztása), így a KAP rendszerének átalakítása több szempontból is visszalépésnek tekinthető. Egyrészt továbbra is megmaradt a keresztmegfelelés, ami a zöldítés mellett nehezen indokolható. A támogatásnak a termelésről történő leválasztása fontos része volt a WTO-tárgyalásoknak (különösen a Doha-forduló során), mivel ezáltal vált lehetővé a kifizetések zömének a legkedvezőbb, korlátozás nélkül adható zöld dobozba történő sorolása (Jámbor-Mizik [2014]). A termeléshez kötött támogatások visszahozása, illetve annak - bizonyos feltételek teljesülése mellett - akár 15 százalékos mértékre történő növelése részben visszafordította ezt a folyamatot. Továbbá, ha a 2003ban bevezetett modulációt ${ }^{6}$ és annak eredményeit pozitívan értékeljük, akkor ennek hatását egy lépésben semmissé tette, hogy lehetővé vált bármelyik pillér pénzügyi keretéből a másikba egy egyszeri, maximum 15 százalékos átcsoportosítás. Ráadásul a kifizetések technikai lebonyolítása is változatlanul eltér a tagországok között.

\footnotetext{
${ }^{4}$ A számítások alapjául szolgáló adatok folyamatosan frissítésre kerülnek, arra azonban a honlap is felhívja a figyelmet, hogy az eredmények tájékoztató jellegűek. A pontos kifizetési összeg meghatározására kizárólag az összes igénylés beérkezése után van lehetőség, azonban nagyságrendileg mindenképpen helytállók az így kapott értékek.

A keresztmegfelelés (cross-compliance) vagy kölcsönös megfeleltetés azt jelenti, hogy a termelöknek bizonyos környezetvédelmi, élelmiszer-biztonsági, növény- és állategészségügyi, illetve állatjóléti elöírásoknak kell megfelelniük (bővebben lásd Jámbor-Mizik [2014]).

${ }^{6}$ A moduláció a közvetlen támogatások bizonyos szint(ek) feletti átcsoportosítását jelentette az első pillérből a második pillérbe (bővebben lásd Jámbor-Mizik [2014]).
} 


\section{Szakirodalmi áttekintés a Cioloș-reformról}

Az első pillér esetében a 2013-as reform egyik legjelentősebb újítása a zöldítés volt, azonban amiatt, hogy ez a tervezetthez képest mekkora környezeti elönyöket képes elérni, már előzetesen is sok kritika hangzott el. Ennek kapcsán Matthews [2013] kiemelte a várhatóan csekély hatást, illetve a keresztmegfelelés és az agrár-környezetgazdálkodás céljaival történő jelentős átfedést. Az Európai Számvevőszék (European Court of Auditors, ECA) egyik tanulmánya szerint ez lényegében a keresztmegfelelés további kiterjesztése, holott még az sem érte el a kívánt hatást (ECA [2008]). Alapvetően a mérhetőség, valamint az ok-okozati kapcsolat kérdésessége miatt „zöldre mosásnak” (greening vs. greenwashing) is aposztrofálhatjuk ezt a problémát (Alons [2017]). Érdemes kiemelni azt is, hogy az elöírások betartása a farmok zömétől nem igényelt érdemi erőfeszitéseket ( $E B$ [2017]). Az adatok alapján a farmok területének közel felét, valamint a termelők 89 százalékát nem érintette (Greer [2017]). Az intézkedés egyik tervezett hozama a pozitív externáliák erősítése és a negatívak csökkentése volt. Solazzo és szerzőtársai [2016] ezt a kérdést az üvegházhatású gázok kibocsátásának szempontjából vizsgálta Olaszországban, azonban csak 1,5 százalékos csökkenést mutatott ki. Ez alapvetően abból adódott, hogy a zöldítés alig volt hatással a tejszektorra, amelyik pedig az üvegházhatású gázok fő kibocsátója (Solazzo és szerzőtársai [2016]).

Önmagában a degresszivitást is sok kritika érte. Egyrészt eleve több tagország (például Csehország, az Egyesült Királyság, Németország, Olaszország vagy Románia) elutasította, mivel az intézkedés az üzemméret alapján diszkriminál (Sahrbacher és szerzőtársai [2015]). Másrészt alig volt érdemi hatása, hiszen például 2015-ben mindössze 109 millió eurót tett ki az EU-ban, aminek a kétharmadát (69 millió eurót) Magyarországon vonták el (Matthews [2016] 27. o.). Harmadrészt a pénzek elosztása ezzel nem lett feltétlenül igazságosabb, mivel a kisebb gazdaságoknak van gazdaságon kívüli jövedelmük, valamint a támogatások csökkentése kevésbé versenyképes mezögazdasági struktúrát alakít ki a nagyüzemek esetében (Matthews [2017]). Negyedrészt elmondható, hogy mindössze kilenc tagállam maximalizálta a közvetlen kifizetéseket (Magyarország mellett Ausztria, Belgium, Bulgária, Egyesült Királyság - kivéve Anglia -, Görögország, Írország, Lengyelország és Olaszország), ${ }^{7}$ vagyis a tagállamok zöme mindössze a kötelezö, 150 ezer euró feletti 5 százalékos elvonást alkalmazta (Matthews [2018]). Emellett azt sem szabad figyelmen kívül hagyni, hogy az érintett nagyüzemek kisebb termelési egységekre bontásával az intézkedés hatásai akár ki is küszöbölhetök. A Cioloş-reform emiatt érdemben érintette a magyarországi mezőgazdasági termelöket - elsősorban a nagyüzemeket - a kifizetések maximalizálása (capping) kapcsán. Mindez versenyképességi szempontból hátrányos, mivel az Európai Unióban a termelés és növekedés motorjai egyértelmüen a nagygazdaságok (Mizik [2019]).

A fiatal gazdák támogatásának célja a generációváltás elősegítése a mezőgazdaságban. Az Eurostat [2017] adatai alapján erre óriási szükség van, mivel az EU28-ban a 65 évesek és annál idősebbek aránya 2,4 százalék, azonban a mezőgazdaságban 9 százalék. Ez

\footnotetext{
${ }^{7}$ Ráadásul ezen országok közül Ausztria, Bulgária, Görögország és Olaszország lehetővé tette a személyi kifizetések levonását a maximalizálás (capping) előtt (Matthews [2018]).
} 
utóbbi arányszám óriási eltéréseket takar az egyes országok között, így például Portugáliában 41,6 százalék, amit Írország (21,7 százalék) és az Egyesült Királyság (18,6 százalék) követ, míg Spanyolországban vagy Lengyelországban 1,8 és 3,2 százalék.

Az eddigi empirikus eredmények vegyesek, bár a fiatal gazdák támogatásának pozitív hatása tagadhatatlan, az Európai Unió szintjén ez megkérdőjelezhető, KeletKözép-Európában sokkal inkább a kiterjedt kistermelöi körrel kapcsolatos probléma részeként érdemes elemezni (Zagata-Sutherland [2015]). Peerlings és szerzőtársai [2014] regressziós eredményei alapján az ágazatot legnagyobb valószínűséggel elhagyó gazdaságok jellemzője, hogy erősen függnek a KAP-támogatásoktól, döntően bérelt földön gazdálkodnak, és vegyes termelést folytatnak. Ezzel szemben a fiatal vezetőjü, specializált gazdaságok a legellenállóbbak, amelyek a KAP érdemi változása esetén is folytatnák a mezőgazdasági termelést. Bár a közeljövőre nézve nem reális opció a támogatások teljes leépítése, azonban a KAP nélküli forgatókönyvek alapján valószínűsíthető, hogy a legfontosabb hatás a koncentrációs nyomás csökkenése lenne (Bartolini-Viaggi [2013]). A KAP költségvetési súlyának további csökkenése biztosra vehető, a Bizottság álláspontja alapján 2021-2027-ben már csak 29 százalék lesz a 2014-2020-as 38 százalékhoz képest (Kengyel [2019]).

\section{A Cioloș-reform hatásai a magyar mezőgazdaságra}

A fejezet A reform legfontosabb elemei címü alfejezetben bemutatott sorrendet követi, vagyis a hatások az alaptámogatás, zöldítés, termeléshez kötött támogatás, fiatalgazda-támogatás, valamint a kisgazdaságok átalánytámogatása sorrendben kerülnek elemzésre és bemutatásra.

\section{Alaptámogatás}

Mivel az alaptámogatás a nemzeti boríték legjelentősebb eleme (közel 54 százaléka, nagyságrendileg közel 50 ezer forint/hektár), és kizárólag ezt érinti a kifizetések csökkentése és maximalizálása, ezért itt lehet legmarkánsabban megfigyelni az érintett termelési egységek alkalmazkodását. ${ }^{8}$ Természetesen nem szabad figyelmen kívül hagyni a földtörvény változásának a hatásait sem, mivel a 2013. évi CXXII. törvény alapján 1200 hektár lett a birtokmaximum, míg az állattartó telep üzemeltetője, a szántóföldi és kertészeti növényfajok vetőmagjának előállítója esetében 1800 hektár (kedvezményes birtokmaximum). A gazdasági szervezetek számának és üzemméretének alakulását mutatja be a 2. táblázat a KSH gazdaságszerkezeti $(2013,2016)$ és egy általános mezőgazdasági összeírásának (2010) az adatai alapján.

\footnotetext{
${ }^{8}$ A 2013 előtti rendszerhez képest a változás nem túl jelentős, mivel - leegyszerűsítve - annyi történt, hogy a korábbi egyösszegü területalapú támogatást két részre bontották (alaptámogatás és zöldítés). Ugyanakkor az már érdemi eltérés, hogy a támogatás nagyobb részét kitevő alaptámogatást érintheti a degresszivitás és a kifizetések maximalizálása, amire az előző időszakban csak a sokkal kisebb jelentőségü moduláció hatott.
} 
2. táblázat

A gazdasági szervezetek számának és üzemméretének alakulása, 2010-2016

\begin{tabular}{lccc}
\hline & 2010 & 2013 & 2016 \\
\hline $\begin{array}{l}\text { Gazdasági szervezetek (ezer darab) } \\
\begin{array}{l}\text { Gazdasági szervezetek által használt terület } \\
\text { (hektár) }\end{array}\end{array}$ & 2191548 & 2121676 & 1945917 \\
$\begin{array}{l}\text { A gazdasági szervezetek átlagos üzemmérete } \\
\text { (hektár) }\end{array}$ & 274,97 & 262,26 & 207,28 \\
\hline
\end{tabular}

Forrás: KSH [2019b] adatok alapján saját számítás.

A táblázat alapján a vizsgált időszakban jelentős változás figyelhető meg a gazdasági szervezetek számát illetően: 2016-ban érdemben (16 százalékkal) növekedett 2013hoz viszonyítva. A gazdasági szervezetek által használt területek 2010 óta kismértékben csökkentek. A két folyamat együttesen a megművelt terület átlagos nagyságának érdemi csökkenését jelenti: 2016-ra a 2010. évi méret egyharmadára csökkent (274,97-ról 207,28 hektár/gazdaságra). Ebben kisebb szerepe volt a megművelt összterület csökkenésének (számláló), sokkal nagyobb szerepet játszott benne a termelési egységek számának a növekedése (nevező). Mindkét, korábban bemutatott szabályozási változás (az alaptámogatás maximalizálása, valamint a korábbinál kisebb birtokmaximum) erősítette ezt a folyamatot. Mindezt a KSH részletes adatai is alátámasztják, mivel a 2500 hektár feletti területen gazdálkodók száma és az általuk használt terület 12-13 százalékkal csökkent 2010-2013 között, majd az azt követö három évben a számuk közel a felére esett vissza, míg a müvelésükben lévő területek nagysága 40 százalékkal csökkent (KSH [2016]).

A közvetlen kifizetésben részesülő gazdaságokat vizsgálva, megállapítható, hogy az 1200 hektár feletti üzemek száma a 2012-es 477-ről 2016-ra 259-re csökkent, valamint ezzel ellentétesen a 600-1200 hektár közöttieké ugyanezen időszakban 556-ról 773-ra nőtt (Szerletics [2018]). Ez a gyakorlatban azt jelenti, hogy az 1200 hektár termőterületnél jelentősen többet használó gazdaságok több vállalkozásra bontva folytatták a müködésüket, hogy ezzel egyrészt megfeleljenek a törvényi elöírásoknak, másrészt pedig ne veszítsék el a jogosult területeik után az alaptámogatást. Ennek következtében azonban nem jelenthető ki egyértelműen, hogy ezáltal érdemben csökkenne a társas vállalkozások termelési hatékonysága vagy kibocsátása, mivel a szétválást követően is kellően nagy maradt az üzemméret, ami lehetővé teszi a kapacitások korábbihoz hasonló kihasználását.

\section{Zöldités}

A területalapú támogatásnak kötelezően a 30 százalékát teszi ki a zöldítés, ez összegszerűen valamivel több, mint 26 ezer forintot jelentett hektáronként 2018-ban (https://www.nak.hu/kapcalk). Ez az összeg kellően motiváló arra, hogy az érintett termelői kör teljesítse az ehhez szükséges feltételeket. A terménydiverzifikáció 
önmagában a termelésből származó jövedelem alapszintü diverzifikációját jelenti, ezáltal valamilyen szinten védelmet nyújt az esetlegesen bekövetkező egyedi, döntően időjárási hatások ellen, mivel több növényi kultúra együttes termelése esetén csökken az esélye annak, hogy mindegyik egyformán érintettje legyen valamilyen negatív természeti hatással. A termelés ilyen módon történő diverzifikálása a művelt terület nagyságával arányosan nő, vagyis nem okozott/okoz megoldhatatlan problémát. Ugyanez igaz az állandó gyepterülettel kapcsolatos fenntartási kötelezettségre. Az ökológiai célterület kialakítása azonban már magában hordozott valamennyi kihívást, mivel mindenképpen újdonságként hatott. A termelők informálása érdekében a Nemzeti Agrárgazdasági Kamara minden évben kiad egy kézikönyvet, valamint kifejlesztett egy zöldítési kalkulátort is, amely tartalmazza azon tájképi elemeket és az egyéb, ökológiai jelentőségü területnek minősülő területeket, amelyek segítségével az 5 százalékos érték elérhető (Kovács és szerzőtársai [2018]).

A tapasztalatok azt mutatják, hogy a termelők a legkisebb ellenállás irányába mozdultak el, vagyis az ökológiai célterületet jellemzően a mezőgazdasági termelés keretein belül alakították ki. A Magyar Államkincstár adatai alapján elmondható, hogy az eddigi években a nitrogénmegkötő növények, ${ }^{9}$ az ökológiai jelentőségű másodvetés ${ }^{10}$ és a parlagon hagyott területek szolgálták ezt a célt, ugyanis ezek tették ki a súlyozás nélküli EFA-területek több mint 90 százalékát (FM [2017]). ${ }^{11}$ Azt azonban fontos megemlíteni, hogy 2018-tól kezdve ezeken a területeken nem lehet növényvédőszert használni, ugyanakkor pozitívum, hogy nitrogénmegkötő növényekkel bevetett terület esetében a súlyozási tényező 0,7-ről 1-re nő (Kovács és szerzőtársai [2018]). A kettő közül azonban az előbbi változás a fajsúlyosabb, ami érdemben visszavetheti még a nitrogénmegkötő növények alkalmazását is, mivel rosszabbak lesznek a kártevők elleni védekezés esélyei, ami jelentősen csökkentheti a termésmennyiséget. A parlagon hagyott területek, illetve az ökológiai jelentőségü másodvetés esetén ugyanakkor jóval kisebb agrotechnológiai változtatások szükségesek, így várhatóan ki fogják váltani a nitrogénmegkötő növényeket (NAK [2018]). Ezt a hatást azonban csak később lehet kimutatni a statisztikai adatok alapján.

A KSH adatai szerint egyértelmü, hogy a két legjelentősebb nitrogénmegkötő növény Magyarországon a lucerna és a szója, amelyek közül az előbbi szálas, az utóbbi pedig szemes takarmány. Az 1. ábra e kultúrák termőterületének és termésátlagának alakulását mutatja 2013-2017 között.

\footnotetext{
${ }^{9}$ Lehet kizárólag nitrogénmegkötő növény vagy keverék (ekkor az előbbi arányának 50 százalék felett kellett lennie), illetve egyéves vagy évelö, de nagyon fontos, hogy a termesztési időszak egészében az adott földterületen kell lennie, különben nem számolható el EFA-területként (Kovács és szerzőtársai [2018]).

${ }^{10}$ Ennek keretében legalább két faj keverékét kell október 1-jéig elvetni úgy, hogy legalább 60 napig a földön legyen, és a következő évi első növény vetése elött beforgatásra kerüljön (Kovács és szerzőtársai [2018]). Az elszámolható fajok egy része egyben nitrogénmegkötő növény is (például a különféle csillagfürtök, herék, a pannonbükköny vagy a lóbab).

${ }^{11}$ Mindez uniós szinten is hasonló képet mutat, a többi tagállam termelöi is döntően ezt a három lehetőséget használták, a különböző tájképi elemeknek ebből a szempontból csak marginális szerepük $\operatorname{volt}(F M[2017])$.
} 
1. ábra

A lucerna és a szója termőterületének és termésátlagának alakulása, 2013-2017 (ezer hektár)

Ezer hektár

Tonna/hektár

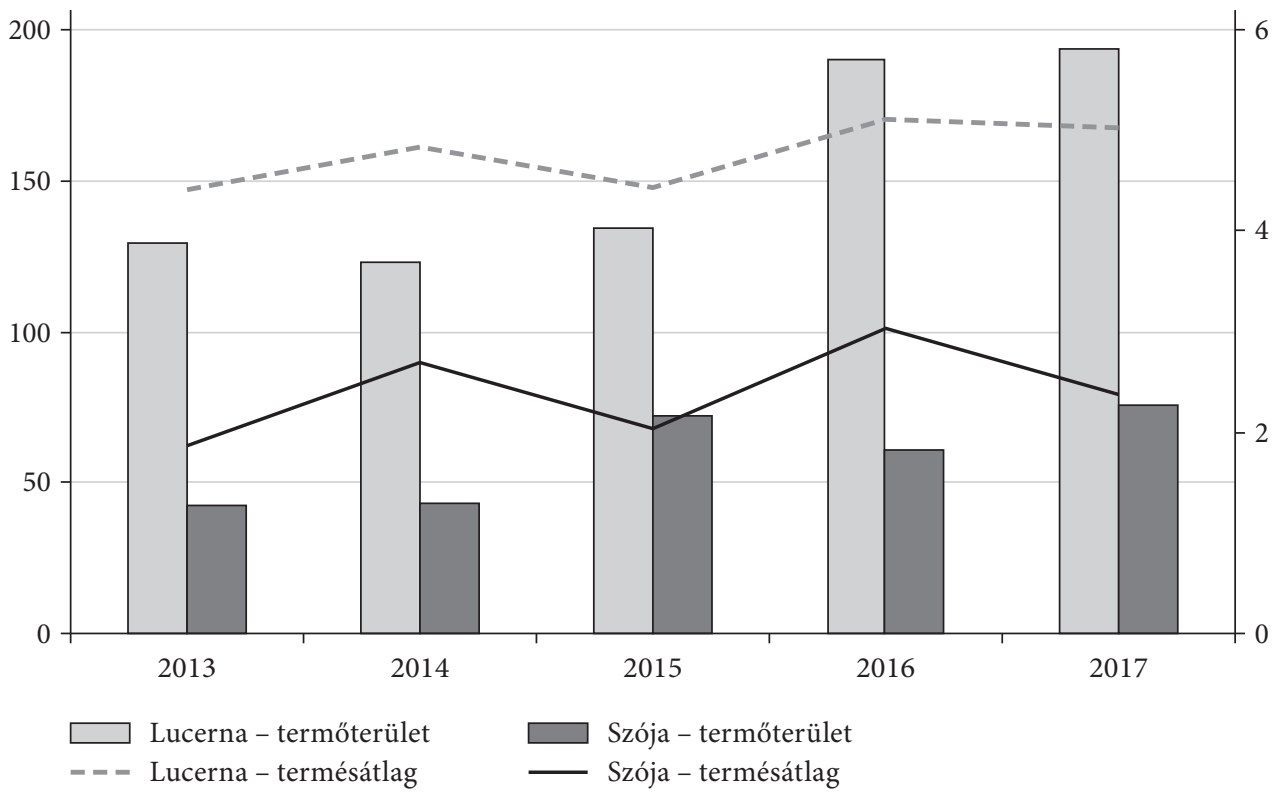

Forrás: KSH [2019d] adatok alapján saját szerkesztés.

Az 1. ábra alapján jól látható, hogy 2014 után mindkét kultúra vetésterülete növekedésnek indult. Mivel a korábbi években nem volt érdemi elmozdulás, így valószínüsíthető, hogy a növekedés legfőbb oka a zöldítés kapcsán bevezetett EFA-terület kialakítása, valamint a termeléshez kötött (szemes/szálas) fehérje támogatása volt.

\section{Termeléshez kötött támogatás}

Bár a KAP a 2003-as reformmal elindult a termeléstöl elválasztott támogatási rendszer irányába, azonban a 2013-as reform lehetővé tette, hogy a tagállamok a közvetlen kifizetések egy részét a termeléshez kössék. A keretösszegeket előzetesen meghatározták, így az elérhető támogatás nagysága a jogosult egyedszámtól, illetve a terület nagyságától függ. Mindegyik jogcím esetében van lehetőség előleg folyósítására, ami érdemi segítséget jelent az ágazat szereplőinél előforduló likviditási problémák kezelésében. Az előlegfizetés nagysága a támogatás végső értékéhez képest eltérő az egyes jogcímek esetén. Alapvetően attól függ, hogy milyen mértékben merülhetnek fel jogvitás vagy adategyeztetést igénylő esetek - ez az állategyed-alapú támogatásoknál nem jellemző, így ott közel maximális kifizetés történik meg, míg a területalapú jogcímeknél általában 50 százalék körüli az előleg nagysága (Vásáry [2018]). A 3. táblázat a 2018-as előleg maximális értékét, a várható fajlagos, valamint a tényleges támogatási összeg nagyságát mutatja be. 


\section{3. táblázat}

Az egyes támogatási jogcímekre kifizethető előleg maximális értékei és a várható fajlagos, valamint a tényleges támogatási összeg, 2018 (forint)

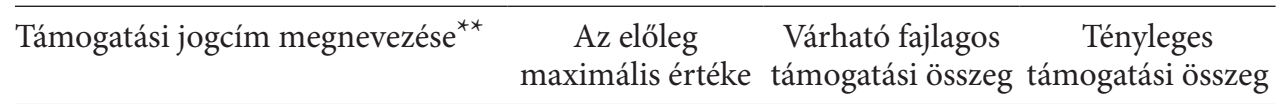

\begin{tabular}{lrrr}
\hline Anyajuhtartás & 5621 & 8030 & 8134 \\
Anyatehéntartás & 32145 & 45921 & 49711 \\
Hízottbika-tartás & 11660 & 16657 & 17188 \\
Tejhasznú tehéntartás & 73576 & 105108 & 105358 \\
Rizstermesztés & 159874 & 228392 & 228912 \\
Cukorrépa-termesztés & 120179 & 171685 & 173194 \\
Zöldségnövény-termesztés & 66223 & 94605 & 92866 \\
Ipari zöldségnövény termesztése & 44794 & 63992 & 63549 \\
Ipari olajnövény termesztése & 53935 & 77049 & 77332 \\
Extenzív gyümölcstermesztés & 52185 & 74551 & 76082 \\
Intenzív gyümölcstermesztés & 92633 & 132333 & 139082 \\
Szemesfehérjetakarmány-növény & 45612 & 65160 & 65729 \\
termesztése & & & 24384 \\
Szálasfehérjetakarmány-növény & 16989 & 24270 & \\
termesztése & & &
\end{tabular}

* Ennek megkezdésére október 16-tól van lehetőség, igazodva ahhoz, hogy a közvetlen kifizetések esetében a pénzügyi év október 15-től október 15-ig tart (EC [2004]).

** 9/2015. (III. 13.) FM rendelet a termeléshez kötött közvetlen támogatások igénybevételének szabályairól.

Forrás: 31/2018. (X. 15.) AM rendelet 1. melléklete, Oláh [2018] és MÁK-adatok.

A táblázatban a rizstermesztés támogatási értéke a legmagasabb, azonban 2017-ben mindössze 86-an kaptak ilyen támogatást, valamint a KSH [2019c] adatai alapján az is látható, hogy az utóbbi években rendre 3000 hektár alatt maradt a termőterület nagysága. Ugyancsak magas a támogatás a cukorrépa esetében, azonban az ágazatra jellemző komplex termeltetési szerződések megkötésére már csak az egyetlen megmaradt cukorgyár, a kaposvári közelében van lehetőség. A várható fajlagos és a tényleges támogatási összeg között pedig minimális az eltérés, tehát az agrárminisztérium vonatkozó rendelete alapján nagyságrendileg pontosan kalkulálható a későbbiekben folyósításra kerülő támogatás. Az eltérés alapvetően két tényezőtől függ: a folyósításhoz használt euróárfolyamtól, valamint az igényléseknek az előző évhez viszonyított tényleges nagyságától (nagyobb állatlétszám, illetve terület esetén csökken a támogatás nagysága, míg kisebbnél nő).

A Magyar Államkincstár (MÁK) adatszolgáltatása alapján látható, hogy a források felhasználásában jelentős különbségek vannak az egyes jogcímek között. Az állati jogcímek mellett a négy legjelentősebb növényi támogatás a szemes és a szálas fehérjenövények, az ipari zöldségnövények termesztése és a gyümölcstermesztés voltak. Ezt szemlélteti a 2. ábra. 
2. ábra

A kifizetések alapján az állati és a négy legjelentősebb növényi támogatási jogcím, 2017 (százalék)

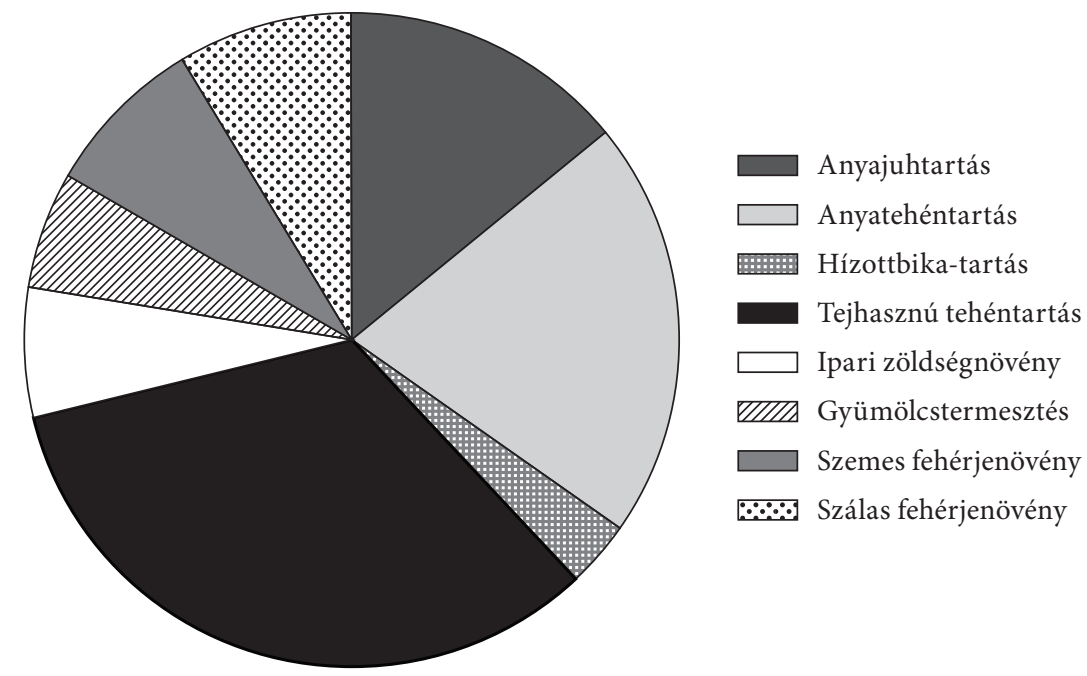

Forrás: MÁK-adatok alapján saját szerkesztés.

A 2. ábra alapján jól látható, hogy a termeléshez kötött támogatások zöme az állattenyésztési ágazatban hasznosul (összességében 70 százalék feletti a részarányuk az ábrán szereplő támogatási jogcímek összegéből), azok közül is kiemelkedő a tejhasznú tehéntartás. Kiemelésre érdemes, hogy a szarvasmarha-ágazatban az átlagosnál is jelentősebb a támogatások szerepe, az agrártámogatások átlagos aránya az adózás előtti eredményből 130-170 százalék között mozog (Czerván [2017]). Emiatt várható, hogy a termeléshez kötött támogatások révén elindul az állatállomány növekedése. Ennek alakulását szemlélteti a 4 . táblázat.

\section{4. táblázat}

A szarvasmarha-állomány és naturális mutatóinak alakulása, 2013-2017

\begin{tabular}{ccccc}
\hline Év & $\begin{array}{c}\text { Szarvasmarha-állomány } \\
(\text { ezer darab) }\end{array}$ & $\begin{array}{c}\text { Tehénállomány } \\
\text { (ezer darab) }\end{array}$ & $\begin{array}{c}\text { Tehéntej } \\
\text { (millió liter) }\end{array}$ & $\begin{array}{c}\text { Egy tehénre jutó } \\
\text { tejtermelés (liter) }\end{array}$ \\
\hline 2013 & 782,4 & 344,8 & 1726,2 & 6933 \\
2014 & 802,1 & 358,9 & 1826,4 & 7248 \\
2015 & 820,5 & 367,6 & 1890,3 & 7501 \\
2016 & 852,2 & 382,7 & 1867,8 & 7562 \\
2017 & 869,7 & 394,7 & 1915,8 & 7820 \\
\hline
\end{tabular}

* A számítás sajátosságai miatt (például még nem tejelő tehén, anyatehén) az egy tehénre jutó tejtermelés nem számolható ki a táblázatból a tehéntejtermelésnek és a tehénállománynak a hányadosaként.

Forrás: KSH [2019f], [2019g] alapján saját szerkesztés. 
A 4. táblázat alapján látható, hogy 2013 óta folyamatosan nő a szarvasmarhaállomány, amiben komoly szerepe van a tehénállomány szintén állandó növekedésének. A tejhasznú tehéntartás támogatási mértéke meghaladja a 100 ezer forintot egyedenként, 2018-ban például 105358 forint volt (3. táblázat). ${ }^{12}$ Ez egyrészt indokolja a támogatások magas arányát az adózás előtti eredményből, másrészt láthatóan motiválja a termelőket az állomány bővítésére. Mindennek a tehéntejtermelésre is pozitív hatása van, amit tovább erősít a tejhozam átlagosan évi 3 százalékos növekedése is. Azt azonban nem szabad figyelmen kívül hagyni, hogy a KSH által felmért állomány szükségszerüen nagyobb, mint a támogatásban részesülő állomány. A MÁK adatai alapján látható, hogy például 2016-ban 182298 anyatehénre, 69668 hízott bikára és 201046 tejhasznú tehénre történt kifizetés (MK [2018] 239. o.). Ez azt jelenti, hogy a szarvasmarha-állomány 52,09 százaléka után kapnak az állattartók támogatást, azonban a tehénállomány esetében már közel 100 százalékos a lefedettség. Valószínüleg ez az oka, hogy a tehénállomány növekedési üteme kismértékben évről évre meghaladja a szarvasmarha-állomány növekedési ütemét (például 2017-ben ez 3,14 százalék volt a 2,05 százalékkal szemben), aminek következtében folyamatosan nő a tehénállomány részaránya is a teljes állományon belül (4. táblázat). Ugyanakkor tovább árnyalja a képet, hogy a szarvasmarha-állomány 2010 óta folyamatosan növekszik (KSH [2019f], [2019g]), holott a 2013-as reform előtti támogatások mértéke a jelenleginél alacsonyabb volt. Ebben a fö szerepet a tartós és erös exportkereslet játssza, ugyanis a magyar húsmarha népszerü termék például Törökországban, ahol ráadásul a piaci árak is magasak (Kelemen [2017]).

A növénytermesztésben a termeléshez kötött támogatás a szemes és a szálas fehérjetakarmány-növény termesztése területén a legjelentősebb. Az előbbinél magasabb a támogatás nagysága (3. táblázat és 1 . ábra), azonban az utóbbi a népszerübb terület (a MÁK adatai alapján 2017-ben 176106 hektár a 81 412-vel szemben), ami elsősorban a lucernát jelenti.

\section{A fiatal gazdák támogatása}

A mezőgazdasági korstruktúra javításának egyik pillére a fiatalgazda-támogatás, amely azonban - a vissza nem térítendő támogatás, illetve a hektáronkénti átalányösszeg mellett - önmagában nem elégséges az ágazatba való belépéshez, ahhoz a termelésnek alapvetően (lehetőség szerint támogatások nélkül) nyereségesnek kell lennie. A közvetlen támogatások között egyébként is viszonylag kis jelentőségű a fiatal gazdák támogatása, mivel mindössze 67,9 euró/hektár a nagysága, és maximum 90 hektár termőföld után lehet igénybe venni ötéves időtartamra, de kizárólag 40 évesnél nem idősebb igénylő esetén, aki ráadásul öt éven belül nyújtott be az egységes területalapú támogatás iránti kérelmet (NAK [2017]). ${ }^{13} \mathrm{Ez}$ a forint/euró árfolyamtól függően

\footnotetext{
${ }^{12}$ Emellett 2020-ig van mód az anyatehéntartás esetében átmeneti nemzeti támogatás folyósítására is, aminek a fajlagos maximális támogatási összege 23110 forint/egyed (Oláh [2018]).

${ }^{13}$ Jelen esetben kizárólag az első pilléres fiatalgazda-támogatást elemezzük, a második pillérből nyújtható, 40 ezer eurós vissza nem térítendő támogatást nem.
} 
hektáronként nagyjából 20-22 ezer forint többlettámogatást jelent az alap- és a zöldítési támogatáson felül. A MÁK adatai alapján 2016-ról 2017-re 10 031-ről 12 722re nőtt a kifizetésben részesülők száma, azonban a kifizetés kismértékben csökkent, ami arra utal, hogy a támogatási rendszerbe újonnan belépők a már bent levőknél átlagosan kisebb területen gazdálkodnak.

Az intézkedés kezdeti hatásait a mezőgazdasági munkaerő állományának összetételén lehet lemérni. Az 5. táblázat a mezőgazdaságban dolgozók számának alakulását és megoszlását mutatja be életkor-kategóriák szerint. A táblázatban a 15-39 év közöttiek (fiatalgazda-támogatásra jogosultak), illetve a 65 évesek és idősebbek vannak, valamint mindkét kategória estében szerepel a nemzetgazdaság egészében az adott kategória értékéhez viszonyított arányuk.

\section{5. táblázat}

A mezőgazdaságban dolgozók számának alakulása és megoszlása életkor-kategóriák szerint, 2013-2017 (ezer fö, százalék)

\begin{tabular}{lrrrrr}
\hline & 2013 & 2014 & 2015 & 2016 & 2017 \\
\hline 15-39 Év KÖzÖTTIEK & & & & & \\
Száma (ezer fö) & 66,9 & 68,6 & 74,6 & 78,4 & 77,2 \\
Aránya az összeshez (százalék) & 3,7 & 3,7 & 4,0 & 4,2 & 4,2 \\
65+ ÉvESEK & & & & & \\
Száma (ezer fö) & 3,6 & 4,1 & 3,3 & 4,3 & 5,0 \\
Aránya az összeshez (százalék) & 11,0 & 13,3 & 9,5 & 10,2 & 10,4 \\
\hline
\end{tabular}

Forrás: Eurostat [2019] adatok alapján saját szerkesztés.

Az 5. táblázatból látható, hogy mind abszolút értékben, mind a 15-39 év közöttiek arányában növekedést mutat a fiatal korosztály nagysága a mezőgazdaságban. Mindez azonban nem jár együtt a korstruktúra hasonló mértékủ javulásával, mivel az időszak egészében a 65 évesek és annál idősebbek száma is nőtt, bár részarányuk (a születéskor várható élettartam növekedésével párhuzamosan) némileg csökkent az azonos nemzetgazdasági kategóriában (11,0 százalékról 10,4 százalékra). Mindez némileg meghaladja az EU28 átlagértékét. Természetesen azt sem szabad figyelmen kívül hagyni, hogy a kategória létszámának alakulását alapvetően az adott években 64 évesek és a termelésből véglegesen kivonulók számának különbsége befolyásolja.

\section{Kisgazdaságok átalánytámogatása}

Amint azt már bemutattuk, a kisgazdaságok átalánytámogatása alapvetően a valóban kis területen gazdálkodók számára jelenthet optimális megoldást, akár a normál rendszerhez képest magasabb fajlagos támogatást minimális adminisztráció mellett. A rendszerbe kizárólag 2015. augusztus 15-ig lehetett belépni, és ezzel éves, átalányjellegü kifizetést kapni 2020-ig, amennyiben a termelő vállalta a jogosult terület 
megtartását. Ez különösen azok számára volt előnyös, akik a normál rendszerben még 500 euró közvetlen támogatást sem kaptak volna, mivel az felkerekítésre került erre a minimumösszegre. Amelyik termelö belépett a rendszerbe, az 2015-ben kizárólag ezt a támogatást kaphatta meg, a normál rendszerbe legkorábban 2016-ban léphetett vissza. A döntésben nemcsak a NAK-támogatás kalkulátora, hanem a falugazdászok is sok segítséget nyújtottak.

A MÁK adatai alapján láthatók ennek a támogatási rendszernek a legfontosabb jellemzői, különös tekintettel az átlagos és a legnagyobb támogatott területre, mert ezek mutatják meg, hogy az érintett termelői kör mennyire hozott racionális döntést (6. táblázat).

6. táblázat

A kisgazdaságok átalánytámogatásának legfontosabb jellemzői, 2015-2017

\begin{tabular}{lccc}
\hline & 2015 & 2016 & 2017 \\
\hline Jóváhagyott terület (hektár) & 109579 & 82725 & 59554 \\
Támogatott ügyfél (fó) & 50000 & 39491 & 30847 \\
Átlagos támogatott terület (hektár) & 2,19 & 2,09 & 1,93 \\
Legnagyobb támogatott terület (hektár) & 54,41 & 9,86 & 9,86 \\
\hline
\end{tabular}

Forrás: MÁK-adatok alapján saját szerkesztés.

A 6. táblázat alapján elmondható, hogy a támogatott ügyfelek számának csökkenésével párhuzamosan csökken a jóváhagyott terület nagysága is. Mindez az átlagos támogatott terület csökkenését is eredményezi, a 2 hektár alatti 2017-es érték pedig abszolút racionális termelői magatartást mutat. Ekkora területnél elképzelhető, hogy még a támogatás minimális összege is nagyobb bevételt jelent, mint amekkorára a normál rendszerben lenne mód. Ugyanakkor az is látható, hogy 2015-ben legalább egy olyan, ezt a támogatási formát választó gazdaság volt, amelyik ezzel biztosan rosszabbul járt, mivel 54,41 hektárral még a maximális, 1250 eurós támogatásnak is a többszörösére lett volna jogosult a normál rendszerben. A táblázatból azonban az is látható, hogy ez a termelő 2016-ban ki is lépett a kisgazdaságok átalánytámogatásából, mivel azóta a legnagyobb támogatott terület 9,86 hektár. ${ }^{14}$ Ennél a területnagyságnál is elképzelhető ugyan, hogy a normál rendszerben több támogatás járna, de egyrészt itt már nem lenne nagyságrendi különbség, másrészt a minimális adminisztráció és a termelési megkötések hiánya ezt ellensúlyozhatja is (például ha a termelő nem kívánja fenntartani az állandó gyepterületét).

Természetesen a fenti adatokból nem derül ki, hogy volt-e, illetve ha igen, akkor hány olyan termelö, aki a normál rendszert választotta, holott a kisgazdaságok átalánytámogatásával jobban járt volna. Amint a „túl nagy” gazdaságok esetében, a NAK ezeknek a termelöknek is külön felhívta a figyelmét erre (bár tény, hogy amíg az első kalapban mindössze 772-en voltak, addig ez utóbbiban mintegy 6000 -en - NAK

\footnotetext{
${ }^{14}$ A kilépés oka lehet az is, ha időközben nőtt a jogosult terület nagysága, ami - a normál rendszerrel ellentétben - a kisgazdaságok átalánytámogatásánál nem jelent nagyobb támogatási összeget.
} 
[2015]). Ennek alapján vélelmezhető, hogy kevesebben csatlakoztak a kistermelöi támogatási rendszerhez úgy, hogy az számunkra hátrányos volt, mint amennyien nem csatlakoztak, holott előnyösebb lett volna számukra.

\section{Összefoglalás és javaslatok}

A 2013-as reform érdemi változásokat hozott az európai mezőgazdasági szektorban, Magyarországot sem hagyva érintetlenül. A reform első pillére lényegi elemének szánt zöldítésre kötelezően a közvetlen támogatás 30 százalékát allokálták, azonban a jelentős számú kivétel (agrár-környezetgazdálkodás, biotermelés, üzemméret stb.), valamint mérhetőségi és ok-okozati problémák miatt a tervezettnél kisebb lett a környezeti hatása. A támogatások degresszivitása, illetve különösen a maximalizálásuk azokban az országokban fejtett ki jelentősebb hatást, ahol a történelmi fejlődés következtében a nagyobb méretü gazdaságoknak érdemi szerepük van a termelésben. Mivel Magyarországon klasszikus duális termelési szerkezet figyelhető meg, így nem véletlen, hogy a 2015-ben az uniós szinten beszedett 109 millió euró kétharmada innen származott.

Tanulmányunk kiinduló hipotézise az volt, hogy a mezőgazdasági termelők alapvetően racionális válaszokat adtak a támogatási rendszer változásaira, vagyis megtettek mindent annak érdekében, hogy a lehető legtöbb támogatást kapják, illetve az előírásoknak a lehető legegyszerübb módon tegyenek eleget. Az alaptámogatás adja a teljes közvetlen kifizetés valamivel több, mint felét, és kizárólag erre vonatkozik a degresszivitás és a maximalizálás (capping). A hektáronkénti közel 50 ezer forintos támogatás a nagyméretű társas vállalkozások számára is elég jelentős volt ahhoz, hogy érdemi lépéseket tegyenek a csökkentés szintjének mérséklése érdekében. Mind a KSH, mind a MÁK adatai azt támasztották alá, hogy a jogosultsági szint feletti gazdaságok egy része kisebb termelési egységekbe szervezte át a müködését, mivel a 2500 hektár feletti üzemek száma csökkent, az 1200 hektár alattiaké pedig nőtt, ugyanakkor a nagyüzemek által használt terület összességében alig csökkent. Tehát a gyakorlatban a támogatás üzemméret szerint történő korlátozása a gazdaságok kisebb részegységekre bontását indította be. A 2020 után várható KAP egyik eleme lehet a kifizetésmaximalizálás összeghatárának jelentős csökkentése, azonban ezúttal a személyi kifizetések kötelező beszámításával (Mizik [2019]). Amennyiben továbbra is feltételezzük, hogy a termelők racionálisak, akkor ennek kettős hatása lesz. Egyrészt a társas vállalkozások esetében megállítja a termelési egységek további szétbontását, aminek hatása annál nagyobb lesz, minél több bevétel származik állattenyésztésből és kertészetből (ezek a szántóföldi növénytermesztésnél sokkal munkaigényesebbek). Másrészt elindítja ezt a folyamatot a nagy területet müvelő, alapvetően gépi munkára támaszkodó egyéni gazdaságoknál, mivel a személyi költségeik alacsony szintje miatt csak minimálisan fogják tudni csökkenteni a támogatásukat a capping elött.

A zöldítés 30 százalékos részaránya szintén elég jelentős volt ahhoz, hogy az érintett termelöi kör teljesítse az ehhez szükséges feltételeket (terménydiverzifikáció, ökológiai célterület kialakítása és állandó gyepterület fenntartása). Ezek közül az első alapvetően 
illeszkedik a termelési struktúrába, mivel a termőterület növekedésével egyenes arányban nő az igény a termelés - és ezáltal az árbevétel - ingadozásának mérséklésére, és az erre irányuló, mezőgazdaságon belüli diverzifikáció (egyidejüleg többféle termény termesztése) egyben a termelők érdeke is. A harmadik feltétel akkor jelenthet problémát, ha a termelö szeretné intenzívebbé tenni a termelését, amire például akkor lehet igény, ha csökken az állatállomány, és már nincs szükség akkora területű gyepre. Az ilyen súlyú döntések azonban hosszú távra szólnak, így a betartásuk nem okoz érdemi gondot egy hét- (a 2015-ös indulás miatt a gyakorlatban hat-) éves időszak alatt. Az ökológiai célterület kialakítása során a termelők egyértelműen a számukra kézenfekvő, mezőgazdasági termelésen belüli megoldásokat alkalmazták, így - sorrendben - nitrogénmegkötő növényekkel, ökológiai jelentőségű másodvetéssel és parlagon hagyott területekkel valósították meg. A növényvédőszer használatának 2018-ban bevezetett tilalma miatt azonban várhatóan érdemben vissza fog esni a nitrogénmegkötő növények vetésterülete, különösen a szójáé. A hazai viszonyok között elérhető, átlagosan 2 tonna/hektár terméshozammal ráadásul nem lehet akkora jövedelmet elérni, mint például a kukoricával, napraforgóval vagy a repcével (Szili-Szlovák [2018]). A zöldítés és a keresztmegfelelés kiváltása az új, kibővített elvárásrendszerrel a támogatások szintjének szempontjából mindössze technikai változtatásnak tünik, a részletek ismeretében azt kell majd mérlegelni, hogy a megfelelés költségei hogyan viszonyulnak az érte kapható többlettámogatás nagyságához.

A termeléshez kötött támogatás hatásait érdemes két részre bontani. A növénytermesztésben a támogatás zömét a szemes és szálas takarmánynövények termelése után fizették ki, amivel a gazdálkodók nemcsak plusztámogatást kaptak, de egyben megfeleltek az EFA-képzési követelménynek is. Az állattenyésztésben a termeléshez kötött támogatás kulcsfontosságú, mivel az ágazat jövedelemtermelő képessége roszszabb a növénytermesztésénél, aminek következtében az agrártámogatások átlagos aránya az adózás előtti eredményből jóval magasabb. A támogatás haszonélvezője alapvetöen a szarvasmarha-ágazat (azon belül is a tejhasznú tehéntartás), amelynek fennmaradásában, illetve az utóbbi években megfigyelhető állománynövekedésében mindenképpen komoly szerepet játszottak a támogatások.

A fiatal gazdák támogatásának célja a mezőgazdasági korstruktúra javítása. A támogatás lényegi része a 40 ezer eurós, vissza nem térítendő támogatás, míg az elemzett támogatási forma hektáronként 20-22 ezer forint többlettámogatást jelent maximum 90 hektáros területnagyságig. Ezzel évente nagyságrendileg 10-12 ezer, 40 évesnél fiatalabb termelő kap pluszforrást. A támogatás hatásait a fiatalok mezőgazdasági szerepvállalásán keresztül lehet mérni. Az adatok alapján elmondható, hogy az utóbbi pár évben nőtt a 40 év alattiak száma a mezőgazdaságban, valamint emelkedett az arányuk is a szektorban az összes, hasonló korú munkavállaló között. Azonban ezzel párhuzamosan nőtt a 65 éves vagy annál idősebbek száma is, az arányuk stabilan 10 százalék felett van. Ezen a területen további intézkedésekre lesz szükség, mivel az elöregedés nemcsak a magyar, hanem az uniós mezőgazdaságnak is a legnagyobb problémája. Erre jól látható módon nem kínál megoldást a jelenlegi nagyságú vissza nem térítendő támogatás és a többlettámogatás kombinációja. Egyrészt egy komplex csomag keretében érdemben növelni kellene a támogatások nagyságát, 
másrészt különböző eszközök segítségével (oktatás-képzés, ösztöndíjprogramok stb.) vonzóbbá kellene tenni a fiatalok számára a mezőgazdasági tevékenységet.

A mezőgazdasági kistermelök 500-1250 euró közötti átalánytámogatást igényelhetnek 2020-ig - jelentős adminisztrációs könnyítés mellett. A NAK támogatáskalkulátora alapján egy hektár jogosult terület felett érdemes volt ezt választani, illetve nagyjából 5,5 hektár felett már mérlegelni kellett, hogy ez vagy a normál támogatási rendszer éri-e meg jobban. A MÁK adatai alapján a belépők átlagos üzemmérete két hektár körüli, tehát így anyagilag jobban jártak. Az előzetes igénylések alapján valószínüsíthető, hogy többen lehetnek azok, akik annak ellenére nem ezt választották, hogy jobban megérte volna számukra, mint amennyien úgy választották, hogy a normál kifizetési rendszerben anyagilag jobban jártak volna. Ez a támogatási forma jól láthatóan szociális elemeket hordoz, mivel évi 150-400 ezer forintból önmagában nem lehet megélni. Az elöregedés miatt a kistermelők folyamatosan kivonulnak a mezőgazdaságból, így ennek a támogatásnak a súlya csökkenni fog az idő elörehaladtával.

Mivel a KAP jövőjével kapcsolatban várható a források csökkenése, illetve más struktúrájú elosztása, így a termelők számára alapvető fontosságú, hogy a várható változásokkal minél előbb tisztában legyenek, és az alkalmazkodáshoz szükséges lépéseket minél előbb megtegyék. Figyelembe véve a támogatásoktól való nagyfokú függőséget, a magyar termelők helyzete várhatóan kevésbé lesz kedvező, ha nem tesznek mielöbbi lépéseket versenyképességük fokozásának érdekében (Mizik [2017]). Az a tapasztalatok alapján viszont jól látható, hogy a gazdasági szereplők racionálisan gondolkoznak, és észszerű válaszokat adnak a támogatási/szabályozási rendszer változásaira, amire a 2020 után várható KAP intézkedései kapcsán is számítani lehet.

\section{Hivatkozások}

Algeier, W. [2015]: Közvetlen termelői támogatások. Magyar Mezőgazdaság, 5. sz. 10-11. o.

Alons, G. [2017]: Environmental policy integration in the EU's common agricultural policy: greening or greenwashing? Journal of European Public Policy, Vol. 24. No. 11. 1604-1622. o. https://doi.org/10.1080/13501763.2017.1334085.

Bartolini, F.-Viaggi, D. [2013]: The common agricultural policy and the determinants of changes in EU farm size. Land Use Policy, Vol. 31. 126-135. o. https://doi.org/10.1016/j. landusepol.2011.10.007.

CZERváN GYÖRGY [2017]: A szarvasmarha-ágazat agrárgazdasági helyzete. Előadás. Magyartarkatenyésztők Egyesülete, szakmai nap, Kocsér, június 22. http://www.magyartarka.hu/tartalom/ fajta/2017/A_szarvasmarha_agazat_agrargazdasagi_helyzete.pdf.

EB [2017]: Az élelmiszer-ágazat és a mezőgazdaság jövője. A Bizottság közleménye az Európai Parlamentnek, a Tanácsnak, az Európai Gazdasági és Szociális Bizottságnak és a Régiók Bizottságának. Európai Bizottság, Brüsszel, november 29. COM(2017) 713 final. https:// ec.europa.eu/agriculture/sites/agriculture/files/future-of-cap/future_of_food_and_ farming_communication_hu.pdf.

EC [2004]: Council regulation on the financing of the common agricultural policy. European Commission, Brüsszel, július 14. COM(2004) 489 final, p. 36. http://www.europarl.europa. eu/RegData/docs_autres_institutions/commission_europeenne/com/2004/0489/COM_ COM(2004)0489_EN.pdf. 
EC [2012]: The Common Agricultural Policy. A story to be continued. European Commission, Luxembourg, https://mediasrv.aua.gr/eclass/modules/document/file.php/AOA167/1.\%20 History_book_lr_en.pdf.

ECA [2008]: Is cross compliance an effective policy? Special Report, No. 8. European Court of Auditors, Luxembourg, https://www.eca.europa.eu/Lists/ECADocuments/SR08_08/ SR08_08_EN.PDF.

Eurostat [2017]: Farmers in the EU - statistics. https://ec.europa.eu/eurostat/statisticsexplained/index.php/Farmers_in_the_EU_-_statistics.

Eurostat [2019]: Employment by sex, age and economic activity (from 2008 onwards). Elérhető: http://appsso.eurostat.ec.europa.eu/nui/show.do?dataset=lfsq_egan2\&lang=en.

FM [2017]: A zöldítés aktualitásai, 2018-tól alkalmazandó változásai. Földmüvelésügyi Minisztérium, Budapest, https://www.kormany.hu/download/8/87/21000/OMEK_FM_ fuzet\%20A5_80_2017_07_11_v2.pdf.

Gravey, V. [2015]: Stronger, not greener? The European Parliament in the 2013 reform of the EU's Common Agricultural Policy. 16th UACES Student Forum Conference, június 29-30. Queen's University Belfast, https://www.uaces.org/documents/papers/1540/gravey.pdf.

Greer, A. [2017]: Post-exceptional politics in agriculture: an examination of the 2013 CAP reform. Journal of European Public Policy, Vol. 24. No. 11. 1585-1603. o. https://doi.org/1 0.1080/13501763.2017.1334080.

Jámbor Attila-Mizıк Tamás (szerk.) [2014]: Bevezetés a Közös Agrárpolitikába. Akadémiai Kiadó, Budapest, 268 o. https://doi.org/10.1556/9789630597869.

Kelemen Zoltán [2017]: A húsmarha húzza fel az állatlétszámot. Világgazdaság, június 8. https://www.vg.hu/vallalatok/husmarha-huzza-fel-az-allatletszamot-2-534695.

Kengyel Ákos [2019]: Az Európai Unió költségvetésének jövője a 2021-2027-es többéves pénzügyi keret tükrében. Közgazdasági Szemle, 66. évf. 5. sz. 521-550. o. https://doi. org/10.18414/ksz.2019.5.521.

Kovács Máté-Kránitz Lívia-Madarász István-Palakovics Szilvia-Pethő JuditRezneki Rita-Szabó Erzsébet-Szerletics Ákos-Sztahura Erzsébet-Tengerdi Gabriella-Zalka-Magyari Rita-Zsemle Viktor [2018]: Zöldítés. Gazdálkodói kézikönyv. Nemzeti Agrárgazdasági Kamara, Budapest, https://www.nak.hu/kiadvanyok/ kiadvanyok/411-zoldites-gazdalkodoi-kezikonyv/file.

KSH [2016]: Agrárium 2016. Statisztikai Tükör, november 22. Központi Statisztikai Hivatal, Budapest.

KSH [2019a]: 4.1.1. Mezőgazdasági számlák rendszere, folyó alapáron (1998-). http://www. ksh.hu/docs/hun/xstadat/xstadat_eves/i_omr002b.html?down=1950.

KSH [2019b]: Agrárcenzusok. Központi Statisztikai Hivatal, Budapest, http://www.ksh.hu/ agrarcenzusok_gszo.

KSH [2019c]: 4.1.14. A fontosabb gabonafélék termesztése és felhasználása (2013-). http://www. ksh.hu/docs/hun/xstadat/xstadat_eves/i_omn001d.html.

KSH [2019d]: 4.1.15. A fontosabb szántóföldi növények termesztése és felhasználása (2013-). http://www.ksh.hu/docs/hun/xstadat/xstadat_eves/i_omn002d.html.

KSH [2019e]: 4.1.16. A fontosabb takarmánynövények termesztése és felhasználása (2013-). http://www.ksh.hu/docs/hun/xstadat/xstadat_eves/i_omn003e.html.

KSH [2019f]: 4.1.26. Állatállomány, december (1995-). http://www.ksh.hu/docs/hun/xstadat/ xstadat_eves/i_oma003.html.

KSH [2019g]: 4.1.24. A fontosabb állati termékek termelése (1990-). http://www.ksh.hu/docs/ hun/xstadat/xstadat_eves/i_oma002.html. 
Matthews, A. [2013]: Greening agricultural payments in the EU's Common Agricultural Policy. Bio-based and Applied Economics, Vol. 2. No. 1. 1-27. o. http://dx.doi. org/10.13128/BAE-12179.

Matthews, A. [2016]: Research for Agri Committee - CAP Reform Post-2020 - Challenges in Agriculture. Workshop documentation. Directorate-General for Internal Policies, Policy Department B: Structural and Cohesion Policies, http://www.europarl.europa.eu/RegData/ etudes/STUD/2016/585898/IPOL_STU(2016)585898_EN.pdf.

Matthews, A. [2017]: The challenges of the next CAP: doing more with less. Agriregionieuropa anno, Vol. 13. No. 50. https://agriregionieuropa.univpm.it/it/content/article/31/50/ challenges-next-cap-doing-more-less.

Matthews, A. [2018]: Why capping will be a mirage. CAP Reform, május 11. http:// capreform.eu/why-capping-will-be-a-mirage.

Mizı́ Tamás [2017]: The past, present and future of the CAP. The Hungarian viewpoint. Megjelent: Wigier, M.-Kowalski, A. (szerk.): The Common Agricultural Policy of the European Union. The present and the future: EU Member States point of view. Instytut Ekonomiki Rolnictwa i Gospodarki Zywnosciowej, Panstwowy Instytut Badawczy, Varsó, 43-61. o. https://doi.org/10.30858/pw/9788376587431.4.

Mızı́ Tamás [2019]: A Közös Agrárpolitika üzemszintű hatásai magyar szemszögböl. Gazdálkodás, 63. évf. 1. sz. 3-21. o.

MK [2018]: B/1360. számú jelentés az agrárgazdaság 2016. évi helyzetéről. Magyarország Kormánya, Budapest, https://www.parlament.hu/irom41/01360/01360.pdf.

NAK [2015]: Vidékfejlesztés. Nemzeti Agrárgazdasági Kamara, Budapest, http://www.nak.hu/ tamogatasok/3327-kedvezo-feltetelek-a-kistermelok-tamogatasaban-augusztus-15-ig.

NAK [2017]: Fiatal mezőgazdasági termelők támogatása. Nemzeti Agrárgazdasági Kamara, Budapest, https://www.nak.hu/kiadvanyok/tamogatasokhoz-kapcsolododokumentumok/rovid-tajekoztatok-egyes-jogcimekrol-tamogatasokrol/1294-fiataltermelok-2017/file.

NAK [2018]: Zöldítés a gyakorlatban - gazdálkodói segédlet. Nemzeti Agrárgazdasági Kamara, Budapest, https://www.nak.hu/kiadvanyok/kiadvanyok/2285-zoldites-agyakorlatban-gazdalkodoi-segedlet/file.

OlÁH ENDRE [2018]: A 2018. évi uniós közvetlen és átmeneti nemzeti támogatások várható alakulása. Mezőgazdasági Szövetkezők és Termelők Országos Szövetsége, http://www. mosz.agrar.hu/ado-szamvitel-tamogatas/1586-a-2018-evi-unios-kozvetlen-es-atmenetinemzeti-tamogatasok-varhato-alakulasa.

Peerlings, J.-Polman, N.-Fries, L. [2014]: Self-reported Resilience of European Farms With and Without the CAP. Journal of Agricultural Economics, Vol. 65. No. 3. 722-738. o. https://doi.org/10.1111/1477-9552.12062.

Sahrbacher, A.-Balmann, A.-Sahrbacher, C. [2015]: The Political Economy of Capping Direct Payments. Applications in - and implications for - Germany. Megjelent: Swinnen, J. F. M. (szerk.): The Political Economy of the 2014-2020 Common Agricultural Policy. An Imperfect Storm. Rowman and Littlefield International, London, 277-306. o. https://www.ceps.eu/ system/files/Political\%20Economy\%20of\%20the\%20CAP_Final_small.pdf.

Solazzo, R.-Donati, M.-Tomasi, L.-Arfini, F. [2016]: How effective is greening policy in reducing GHG emissions from agriculture? Evidence from Italy. Science of the Total Environment, Vol. 573. 1115-1124. o. https://doi.org/10.1016/j.scitotenv.2016.08.066.

Swinnen, J. F. M. (szerk.): The Political Economy of the 2014-2020 Common Agricultural Policy. An Imperfect Storm. Rowman and Littlefield International, London, https://www.ceps.eu/ system/files/Political\%20Economy\%20of\%20the\%20CAP_Final_small.pdf. 
SzABó ANDREA [2017]: Közös Agrárpolitika. Infojegyzet. Képviselöi Információs Szolgálat, 44. sz. május 26.https://www.parlament.hu/documents/10181/1202209/Infojegyzet_2017_44_kozos_ agrarpolitika.pdf/d16165ec-a0e4-4aad-a56f-09c894ac2c7d.

Szerletics Ákos [2018]: Degressivity, capping and European farm structure: New evidence from Hungary. Studies in Agricultural Economics, Vol. 120. No. 2. 80-86. o. https://doi. $\operatorname{org} / 10.7896 /$ j.1811.

SzILI ViKToR-Szlovák SÁNdor [2018]: A főbb mezőgazdasági ágazatok költség- és jövedelemhelyzete. 2016. Agrárgazdasági Információk, Agrárgazdasági Kutató Intézet, Budapest, http://repo.aki.gov.hu/3197/1/2018_AI_03_Agazatok\%20kiadvany\%20KO\%CC\%88 LTSE\%CC\%81GE\%CC\%81S\%20JO\%CC\%88VEDELEMHELYZETE_web_pass.pdf.

VÁsÁRY MikLós [2018]: Kezdődik az előlegfizetés! Agro Napló, 22. évf. 11. sz. 6-7. o. https:// www.agronaplo.hu/szakfolyoirat/2018/11/aktualis/kezdodik-az-elolegfizetes.

Zagata, L.-Sutherland, L.-A. [2015]: Deconstructing the 'young farmer problem in Europe': Towards a research agenda. Journal of Rural Studies, Vol. 38. No. 2. 39-51. o. https://doi.org/10.1016/j.jrurstud.2015.01.003.

\section{Hibaigazítás}

A Közgazdasági Szemle októberi számának 1061. oldalán, Fleischer Tamás Városi mobilitás, közjavak, fenntarthatóság címü cikkének 3. ábráján a vízszintes tengely felirata hibásan jelent meg. A helyes ábra a következő:

3. ábra

Zavartalan $(A-B)$, zavart $(B-C)$ és torlódott $(C-D)$ forgalom a közúti kapacitás tervezése, illetve a közjavak és fenntarthatóság szerint
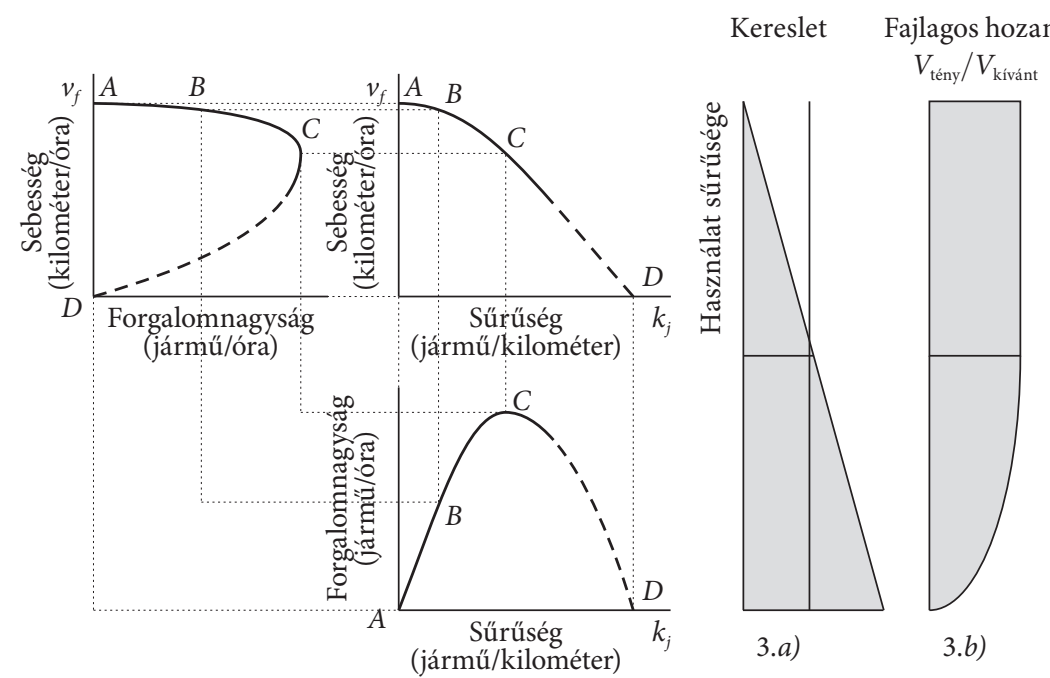

Forgalom-

Forrás: Motorway design... [2017] és saját szerkesztés. 